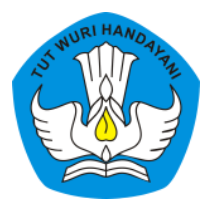

Page: 1-18

\title{
Pengembangan Media Spedomatik pada Pemahaman Konsep Nilai Tempat di Sekolah Dasar
}

\author{
Dedy Dwi Setyawan \\ Sekolah Dasar Negeri Sumberwatu Sleman, Yogyakarta \\ Contributor Email: genggardy@gmail.com
}

Published: Mar 30, 2020

Article Url: http:/ / ojsdikdas.kemdikbud.go.id/index.php/didaktika/article/view/120

\begin{abstract}
The development of Spedomatik media has the aim of strengthening the understanding of mathematical concepts and improving student learning outcomes. This innovation was developed by applying the Research and Development method. The results show that the percentage of student learning outcomes has increased, from before the use of Spedomatik on average only $54.44 \%$ then increased when the trial 1 became $52.22 \%$ and increased in the second trial to $75.55 \%$. Conclusions obtained for the achievement of improvements that occur due to the use of Spedomatik media, where the activeness of students in manipulating Spedomatik is a stage in understanding mathematical concepts.
\end{abstract}

Keywords: Spedomatik, place value, learning outcomes 


\begin{abstract}
Abstrak
Pengembangan media Spedomatik bertujuan utuk meningkatkan pemahaman konsep matematis pada materi nilai tempat bilangan, agar terjadi penguatan konsep matematis dan peningkatan hasil belajar siswa di SD Negeri Sumberatu Kabupaten Seleman. Inovasi ini dikembangkan dengan menerapkan metode penelitian dan pengembangan. Hasil yang diperoleh menunjukan prosentase hasil belajar siswa yang mengalami peningkatan, dari sebelum penggunaan Spedomatik diperoleh ratarata 52,22\%, kemudian mengalami peningkatan saat ujicoba 1 menjadi 54,44\% dan semakin meningkat pada uji coba 2 menjadi 75,55\%. Kesimpulan yang diperoleh atas pencapaian peningkatan yang terjadi dikarenakan penggunaan media Spedomatik, dimana keaktifan siswa dalam mmenggunakan dan emanipulasi Spedomatik merupakan tahapan dalam pemahaman konsep matematis.
\end{abstract}

Kata Kunci: Spedomatik, nilai tempat, hasil belajar

\title{
A. Pendahuluan
}

Permendiknas nomor 22 tahun 2016 menjelaskan pembelajaran matematika di Sekolah Dasar (SD) memiliki tujuan supaya siswa secara luwes, efisien, akurat, dan tepat pada kemampuan memahami konsep, menjelaskan keterkaitan antar konsep atau algoritma dalam pemecahan masalah. Penggunaan multimedia, sumber, alat, peraga, multi metoda, pendekatan, model dan media yang tepat pada pembelajaran matematika di SD harus menjadi perhatian penting guru agar tujuan pembelajaran matematika dapat dicapai siswa melalui pembelajaran yang bermakna,

Menurut Piaget (dalam Savin, 2011) menjelaskan bahwa dalam tahap operasional, pentingnya siswa SD termasuk dalam tahap konkrit yang perlu dialamai siswa. Sehingga, penggunaan media dapat dikatakan amat penting dalam proses pembelajaran matematika di SD. Pentingnya media tersebut mampu membangun konsep pembelajaran matematika agar bermakna bagi siswa. Schweyer (2010:4) berpendapat bahwa pemanfaatan konsep matematika melalui penggunaan media matematika yang dapat didefinisasikan dan dioperasionalkan sebagai objek dunia nyata. Dia menyimpulkan bahwa untuk penggunaan media di SD dapat dilakukan dengan menvisualisasikan hal-hal yang abstrak menjadi konkret dan nyata dalam pikiran siswa. 
Pengalaman mengajar di SD, pembelajaran matematika pada materi nilai tempat suatu bilangan masih banyak siswa yang mengalami kesulitan memahami konsep nilai tempat pada suatu bilangan. Hal tersebut tampak dalam pembelajaran nilai tempat suatu bilangan yang dilaksanakan di kelas 2 SDN Sumberwatu Kabupaten Sleman, dimana siswa mengalami kesulitan dalam memahami nilai tempat suatu bilangan. Setelah dianalisis, pembelajaran yang dilaksanakan guru menggunakan tulisan di papan tulis dengan cara membuat kotak-kotak sekitar 3 buah untuk mengenalkan nilai tempat suatu bilangan. Degan cara tersebut, siswa menjadi tidak terlibat secara langsung dan aktif dalam pembangunan konsep. Hal tersebut, ditemukan bahwa yang menyebabkan siswa kesulitan dalam mengenal bilangan secara utuh, dimana salah satunya siswa harus memahami konsep nilai tempat suatu bilangan.

Atas hal temuan tersebut, didapati nilai rata-rata hasil belajar siswa yang rendah dalam pembelajaran nilai tempat suatu bilangan. Berdasarkan hasil wawancara bersama guru kelas 2, hasil belajar yang rendah pada pembelajaran nilai tempat suatu bilangan hampir terjadi setiap tahunnya. Kesulitan siswa dalam membangun konsep nilai tempat suatu bilangan belum dapat diatasi oleh guru. Disamping itu, guru merasa kesulitan dalam membuat media yang dapat menunjukkan konsep nilai tempat suatu bilangan. Dengan demikian, untuk mendapatkan pembelajaran matematika yang bermakna, guru mengharapkan adanya media yang mampu membantu siswa dalam membangun konsep nilai tempat suatu bilangan.

Untuk mendapatkan pembelajaran yang bermakna, media pembelajaran haruslah dapat dimanipulasi siswa pada saat pembelajaran. Karena dengan terlibat secara langsung dan aktif dalam pembelajaran, siswa diharapkan akan memahami konsep pembelajaran lebih lama daripada siswa yang hanya mendengarkan penjelasan dengan duduk manis. Sesuai dengan pendapat Boggan et al. (2010:2) yang menjelaskan bahwa bila media dimanipulasi dari berbagai bentuk termasuk benda- 
benda fisik, dapat digunakan sebagai media pengajaran yang melibatkan siswa dalam belajar matematika. Atas dasar itu, peneliti mencoba mengembangkan media Spedomatik pada pembelajaran nilai tempat suatu bilangan di SD.

Media Spedomatik merupakan papan stereofoam yang dilapisi kertas karton dengan bantuan lem berbentuk persegi yang ditempelkan 3 buah lingkaran yang berbeda ukuran diameternya, setiap lingkaran dibagi menjadi 10 bagian sama besar. Lingkaran yang ditempel dirancang agar dapat berputar dan masing-masing lingkaran mewakili nilai tempat satuan, ratusan, dan ribuan. Dengan media ini, siswa diharapkan dapat membayangkan dan memahami konsep nilai tempat suatu bilangan, karena media ini mampu memvisualisasikan dan menjadi jembatan pemikiran abstraksi nilai tempat bilangan pada pikiran real atau nyata siswa. Pada aplikasinya siswa dapat memanipulasi 3 buah lingkaran yang mewakili nilai tempat satuan, ratusan, dan ribuan secara langsung kemudian secara bertahap mengetahui nilai tempat bilangan, sehingga media ini mampu membantu siswa pada penanaman konsep nilai tempat bilangan.

Berdasarkan informasi diatas, diharapkan penggunaan media Spedomatik dapat meningkatkan pemahaman konsep nilai tempat bilangan dan mampu meningkatan hasil belajar matematika pada materi nilai tempat bilangan. Kemungkinan siswa mendapatkan pengetahuan dan keterampilan siswa yang bermakna dengan Spedomatik, selain sebagai media belajar.

Mendasari pada latar belakang diatas, rumusan masalah penelitian pengembangan ini adalah sebagai berikut.

1. Bagaimanakah hasil belajar siswa sebelum dan sesudah menggunakan media Spedomatik pada materi nilai tempat bilangan di kelas 2 SD Negeri Sumberwatu Sleman?

2. Bagaimanakah efektifitas penggunaan media Spedomatik pada materi nilai tempat bilangan di kelas 2 SD Negeri Sumberwatu Sleman? 
Penelitian ini bertujuan untuk mendeskripsikan hasil penggunaan Spedometrik dan proses belajar, serta keefektifan penggunakan Spedomatik pada materi nilai tempat bilangan di kelas 2 SD Negeri Sumberwatu Sleman.

\section{B. Metode}

Penelitian pengembangan digunakan dalam penelitian ini dengan mengacu pada metoda penggunaan model 4-D oleh Thiagarajan, dkk (1974:5). Model 4-D terdapat empat tahap pengembangannya, yakni: 1) definisi/ define, 2) perancangan/ design, 3) pengembangan/ develop, dan 4) penyebarluasan/ disseminate.

Tahap defenisi/define adalah tahap dimana dilakukan analisis dan identifikasi tentang kebutuhan dari masalah dasar yang didapati dan dihadapi pada saat pembelajaran nilai tempat bilangan di sekolah dasar. Ketika fokus masalah sudah ditetapkan dalam pembelajaran nilai tempat bilangan, peneliti kemudian mengidentifikasi kurikulum, menganalisis karakteristik siswa dan mengidentifikasi serta menganalisis konsep nilai tempat bilangan secara lebih dalam. Tahap define ini didapatkan sebuah pokok masalah terhadap minimnya pemanfaatan media pembelajaran yang dapat membantu siswa memvisualisasikan konsep absrak pada nilai tempat bilangan dan sebuah pengalaman siswa dalam belajar.

Tahap perancangan/design adalah tahap ke dua yang perancangan menjadi tahap yang merupakan rancangan sebuah media pembelajaran yang dibuat sesuai dengan karakteristik siswa. Media Spedomatik menjadi rancangan untuk digunakan pada pemahaman konsep nilai tempat bilangan. Tahap pengembangan (development) adalah tahap ketiga yang mampu menghasilkan sebuah media yang diberi nama Spedomatik, untuk kemudian dilakukan ujicoba pada siswa SD. Tahap penyebarluasan/disseminate adalah tahap, dimana peneliti melakukan penyebarluasan penggunaan media Spedomatik kepada teman-teman sejawat pada gugus yang sama. 
Inti dari media Spedomatik yaitu pada tiga buah lingkaran yang masing-masing bernilai satuan, puluhan, dan ratusan. Lingkaran tersebut ditempelkan pada papan berbentuk persegi. Setiap lingkaran memiliki warna dan ukuran yang berbeda, yang menjelaskan bahwa nilai satuan, puluhan, dan ratusan itu tidaklah sama Media Spedomatik terbuat dari sterefoam yang dilapisi kertas asturo berwarna hitam dan kardus bekas yang dilapisi kertas asturo warna-warni. Pemilihan sterefoam dan kardus bekas dengan pertimbangan bahwa bahan-bahan membuat media Spedomatik mudah didapatkan sehingga dalam penyebarluasannya akan lebih mudah ditiru dan diterapkan oleh guru lain. Selain itu, bahan bekas yang digunakan dapat mengurangi sampah daur ulang sehingga membantu menjaga kelestarian lingkungan sekitar. Kedepannya untuk memenuhi proses keawetan atau tahan lama media, media Spedomatik akan dicoba dibuat dengan menggunakan kayu dan triplek. Alat dan bahan sederhana dan sangat mudah ditemukan dalam membuat media Spedomatik, diantaranya: 1) Sterefoam, 2) Kertas asturo, 3) Kardus bekas, 4) Lem tembak, 5) Pensil, 6) Spidol hitam, 7) Busur derajat, 8) Gunting, 9) Lem kertas, dan 10) Isolasi ganda.

Jika alat dan bahan sudah siap dan lengkap, maka berikut proses pembuatan media Spedomatik: 1) Membuat papan alas dari bahan sterefoam untuk menempelkan tiga buah lingkaran yang mewakili nilai tempat satuan, puluhan, dan ratusan. Ukuran sterefoam sekitar $60 \times 40 \mathrm{~cm}$ untuk kemudian dilapisi kertas asturo berwarna hitam agar lebih terlihat seperti Spedometer, 2) Membuat tiga buah lingkaran dari kertas kardus yang dilapisi kertas asturo berwarna dengan ukuran yang berbeda. Dari yang terkecil ke terbesar secara berurutan mewakili nilai tempat satuan, puluhan, dan ratusan. Pada masing-masing lingkaran dibagi menjadi 10 bagian sama besar kemudiian diberi angka sesuai nilai tempatnya, untk satuan 0-9, puluhan 00-90, dan ratusan 000-900, 3). Tiga buah lingkaran yang sudah dibuat kemudian ditempelkan pada papan alas secara sejajar dan beriritan sesuai nilai tempat bilangan. Pada titik tengah lingkaran di gunakan paku agar lingkaran dapat diputar, tambahan item panah 
sebagai penunjuk angka, 4) Setelah dijadikan pada satu pada papan alas, media Spedomatik sudah dapat digunakan saat pembelajaran nilai tempat bilangan di kelas 2 SD Negeri Sumberwatu Sleman.

\section{Hasil dan Pembahasan}

Media Spedomatik terinspirasi dari sebuah permainan spin atau lingkaran berputar yang dalam lingkaran tersebut terdapat bagian-bagian yang dapat dipilih dengan menggunakan penunjuk berupa panah, dimana bagian yang ditunjuk panah merupakan bagian yang terpilih. Biasanya digunakan dalam kuis di acara televisi atau undian berhadiah lainnya. Anak usia SD sangat menyukai sebuah permainan karena memang masa usia mereka adalah usia bermain, sehingga dengan menggunakan media ini siswa serasa bermain saat dirinya belajar. Selain itu media Spedomatik pada tampilannya dipadukan dengan tampilan spedometer kendaraan yang memiliki beberapa lingkaran dalam wadahnya, hal ini yang menjadikan nama media ini adalah media Spedomatik. Adapun Spedomatik papan utamanya terbuat dari sterofoam dan item pendukung lainnya dari sebuah kardus dan kertas asturo berwarna. Ide awal pengembangan media Spedomatik dari media gambar kubus yang digunakan di sekolah, gambar tumpukan kubus-kubus kecil yang tersusun menjadi sebuah kubus besar. Setiap kubus itulah yang digunakan untuk menentukan nilai tempat bilangan. Penggunaan media tersebut kurang dapat dimanipulasi anak karena hanya berupa gambar di buku atau papan tulis. Untuk itu, peneliti membuat media Spedomatik berupa papan berbentuk persegi panjang dilengkapi dengan 3 buah lingkaran dari kardus yang dibagi masing-masing menjadi 10 bagian sama besar. Bagian-bagian dalam setiap lingkaran tersebut nantinya yang akan mewakili nilai tempat satuan, puluhan, dan ratusan.

Pada masing-masing lingkaran dibagi menjadi 10 bagian sama besar dengan menggunakan busur derajat, dimana untuk mendapatkan bagian yang sama hitung dengan ukuran masing-masing sebanyak $35^{\circ}$. Setelah itu pada setiap bagian pada masing-masing lingkaran diberi angka 0-9 untuk nilai satuan, 00-90 untuk nilai puluhan, dan 000-900 untuk nilai ratusan. 
Penggunaan ukuran berbeda pada masing-masing lingkaran untuk mempermudah siswa dalam memahami perbedaan nilai tempat ketiganya. Sedangkan pemberian warna berbeda pada masing-masing lingkaran memiliki tujuan supaya siswa tertarik menggunakan media dalam pembelajaran, selain supaya gampang diingatoleh siswa. Senada dengan hasil penelitian Marshall, Linda, \& Paul (2008) yang menjelaskan bahwa siswa merasakan kemudahan dalam menghubungkan dunia real (nyata) dengan konsep yang dikembangkan melalui penggunaan media manipulatif.

Media Spedomatik diciptakan guna menjawab kebutuhan media pembelajaran nilai tempat bilangan yang mampu memenuhi tahapan dalam memahami konsep tentang nilai tempat bilangan, mengurutkan bilangan, dan menjumlah serta mengurangi bilangan sederhana melalui satu media saja. Spedomatik sangat mudah digunakan dan bersifat sederhana, dimana cara menggunakannya hanya dengan memutar-mutar lingkaran yang tersedia sesuai dengan suatu bilangan yang dicari. Sehingga hanya melalui satu media Spedomatik dapat digunakan untuk seluruh konsep nilai tempat bilangan di sekolah dasar. Ide awal media Spedomatik dapat di ilustrasikan sebagai berikut:

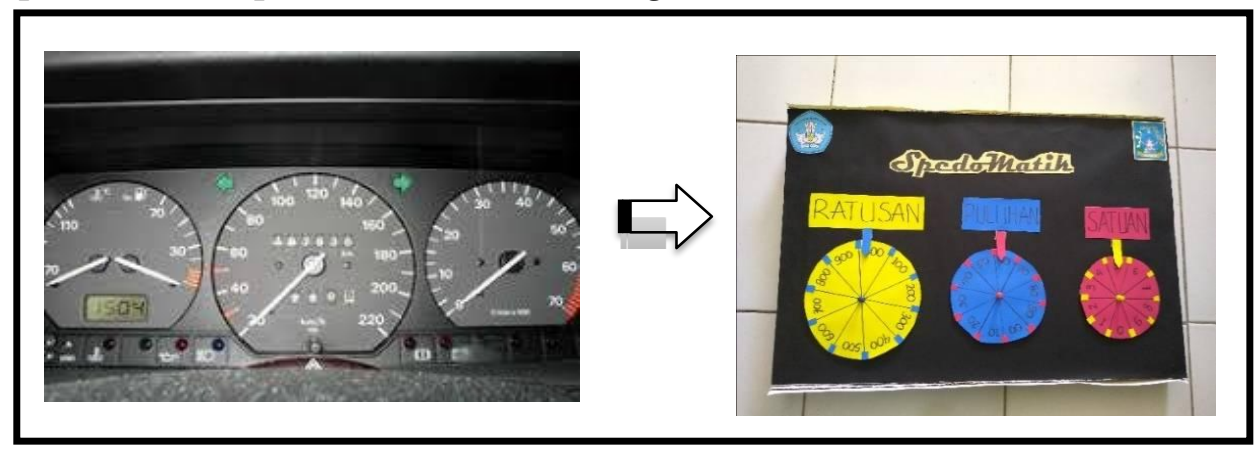

Gambar 3.1 Konsep ide dasar Spedomatik

Proses penemuan media Spedomatik didasari pada kegundahan peneliti ketika mengajar matematika di SD, dimana ditemukan kebanyakan siswa merasakan kesulitan saat menentukan nilai tempat bilangan. Banyak media yang pernah digunakan seperti gambar kubus bertumpuk, sedotan, dan video animasi namun belum mampu memecahkan masalah tentang kesulitan siswa saat menentukan nilai tempat bilangan. Peneliti mengidentifikasi 
kesulitan siswa berdasar atas kemampuan memahami konsep dasar nilai tempat bilangan, sehingga saat mengerjakan soal harian dan soal berkala dalam nilaitempat bilangan siswa merasakan kesulitan. Atas dasar hal tersebut, diperoleh inspirasi bagaimanakah membuat media yang dapat meningkatkan pemahaman konsep nilai tempat bilangan agar siswa mengalami pembelajaran yang bermakna.

Media Spedomatik adalah sebuah jawaban usaha dan doa dari kegalauan peneliti dalam jangka waktu cukup lama dalam mengajar matematika di SD khususnya pada saat materi nilai tempat bilangan. Perasaan gamang dan pedih dengan hasil belajar siswa kelas 2 SD pada soal-soal nilai tempat bilangan cenderung lebih rendah daripada materi lain. Ketika proses pembelajaran, peneliti juga belum mendapatkan sebuah media yang dapat menvisualisasikan konsep nilai tempat bilangan yang abstrak menjadi konkret. Tentu kita tahu, masa belajar matematika di SD merupakan acuan perkembangan belajar siswa pada jenjang yang lebih tinggi sehingga sangat penting sebuah penerapan konsep matematis di SD. Peneliti merasakan munculnya sebuah jalan buntu (missing link) pada pembelajaran nilai tempat bilangan sehingga dibutuhkan media yang mampu memvisualisasikan konsep abstrak nilai tempat bilangan dengan dunia yang nyata (real) bagi siswa.

Inspirasi akhirnya lahir ketika peneliti melihat sebuah acara kuis di televisi, dimana kuis tersebut menggunakan sebuah lingkaran sebagai penentu pilihan. Kemudian hal tersebut coba diterapkan dalam media pembelajaran yang sederhana, bentuk spedometer pada kendaraan bermotor juga termasuk ide awal bentuk media. Dari kedua hal itu munculah ide Spedomatik, atau dapat diterjemahkan sebagai spedometer bulat yang dapat dibulat untuk mengerjakan soal matematika. Pembuatan, pengengmbangan, dan implemetasi media Spedomatik merupakan sebuah solusi atas minimnya media guna menerapkan konsep nilai tempat bilangan di SD. Siswa akan berperan aktif dan terlibat langsung dalam pembelajaran baik secara visual dan kognitif melalui mengamati, menyentuh, menyentuh saat memutar-mutar tiga lingkaran, dan mampu berpikir ketika menempatkan panah pada angka yang dicari. 
Ketika siswa melakukan manipulasi media Spedomatik, hal ini dapat membantu siswa dalam memahami konsep nilai tempat bilangan, dan memudahkan dalam menjumlah serta megurang bilangan sederhana. Tentu hal tersebut merupakan pengalaman manrik bagi siswa, dimana sebelumnya hanya cara pakem dari guru atau buku paket untuk mengerjakan nilai tempat bilangan. Atas dasar itu, penggunaan media Spedomatik mampu meningkatkan pemahaman siswa akan nilai tempat bilangan dan membuat pembelajaran menjadi lebih menarik dan bermakna bagi siswa.

Penggunaan atau aplikasi praktis media Spedomatik dilaksanakan pada pembelajaran di kelas 2 SD Negeri Sumberwatu Sleman. Media Spedomatik digunakan untuk memudahkan siswa menentukan nilai tempat bilangan dan membantu menjumlah serta mengurangi bilangan. Guru sebagai pembimbing dan fasilitator memberikan arahan supaya siswa mampu menggunakan media dengan tepat. Siswa membentuk sebuah kelompok untuk kemudian secara bergiliran menggunakan media Spedomatik untuk meningkatkan pemahaman konsep nilai tempat bilangan.

Secara garis besar, tahapan penggunaan media Spedomatik dapat dijabarkan sebagai berikut: 1) Guru memberikan permasalah kontekstual yang harus siswa selesaikan dalam kelompok, 2) Siswa mencoba memberikan saran pemecahan masalah, 3) Guru mengajak siswa melakukan diskusi kelompok dengan bantuan media Spedomatik dan Lembar Kerja Siswa, 4) Guru mengenalkan media Spedomatik pada siswa dan bagaiama cara menggunakannya, 5) Peserta didik menyelesaikan soal nilai tempat melalui soal terbimbing dalam LKS, 6) Guru membantu kesulitan kelompok siswa.

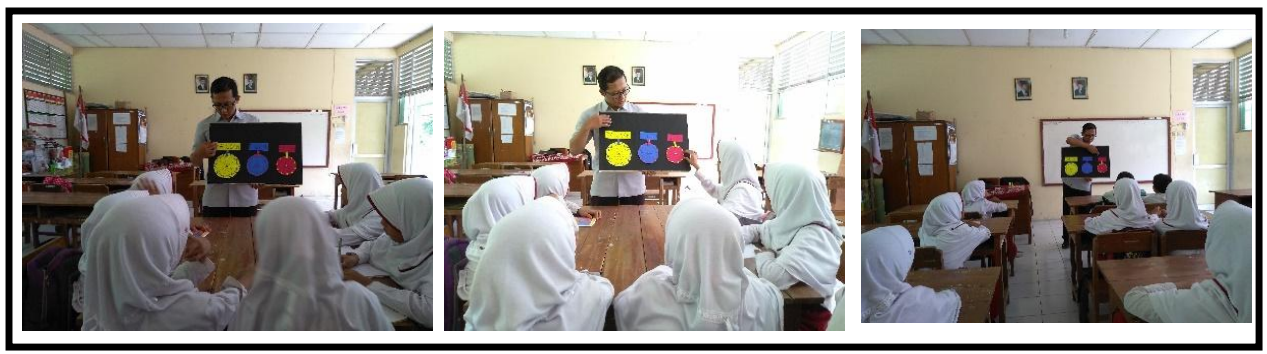

Gambar 3.6 Mengenalkan Spedomatik kepada siswa 
Penarapan media Spedomatik pada materi nilai tempat bilangan dapat dijelaskan sebagai berikut:

\section{Menentukan Nilai Tempat Bilangan}

Dalam menentukan nilai tempat bilangan pada Spedomatik sangatlah sederhana, dimana siswa tinggal memutarkan tiga buah lingkaran (satuan, puluhan, ratusan) dan memilih angka yang sesuai dengan soal pada tanda panah masing-masing lingkaran. Siswa hanya melihat angka bilangan yang sama dengan yang terdapat pada soal.

Contoh soal, tentukan nilai tempat bilangan 236 !

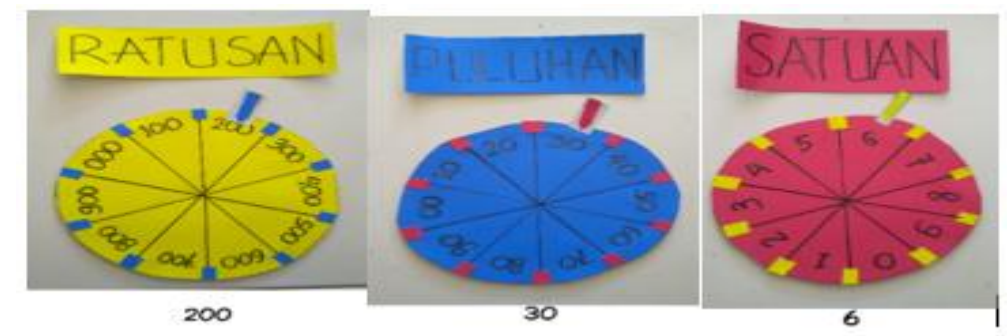

Gambar 3.7 Ilustrasi penggunaan Spedomatik

Hasil yang didapat adalah 200 sebagai ratusan, 30 sebagai puluhan, dan 6 sebagai satuan. Dengan bantuan Spedomatik siswa akan lebih mudah menentukan nilai tempat bilangan.

\section{Penjumlahan Bilangan}

Penjumlahan bilangan dengan Spedomatik langkahnya sangat sederhana. langkah pertama sama dengan cara menentukan nilai tempat bilangan. Langkah kedua hanya dengan menjumlahkan sesuai dengan nilai tempatnya atau bisa langsung dengan bersusun. Agar lebih jelas dapat melihat gambar berikut ini: 


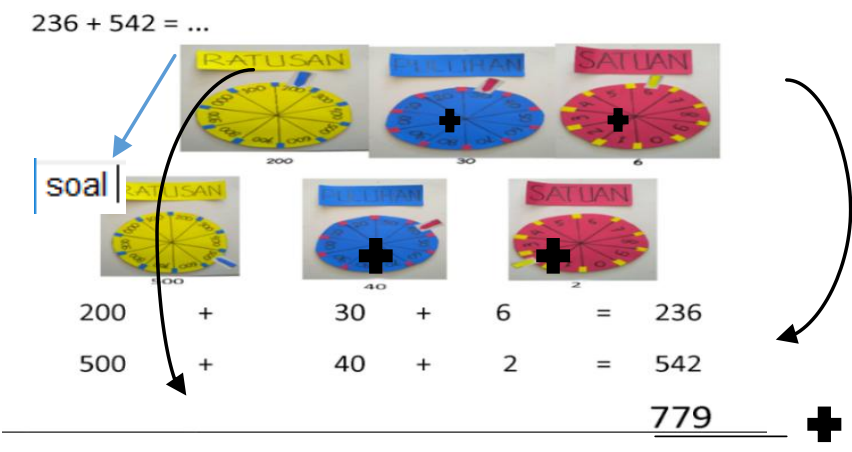

Gambar 3.8 Ilustrasi penjumlahan bilangan dengan Spedomatik

\section{Pengurangan Bilangan}

Pengurangan bilangan dengan Spedomatik langkahnya sangat sederhana. langkah pertama sama dengan cara menentukan nilai tempat bilangan. Langkah kedua hanya dengan mengurangkan sesuai dengan nilai tempatnya atau bisa langsung dengan bersusun. Agar lebih jelas dapat melihat gambar berikut ini:

Contoh soal: $542-236=\ldots .$.

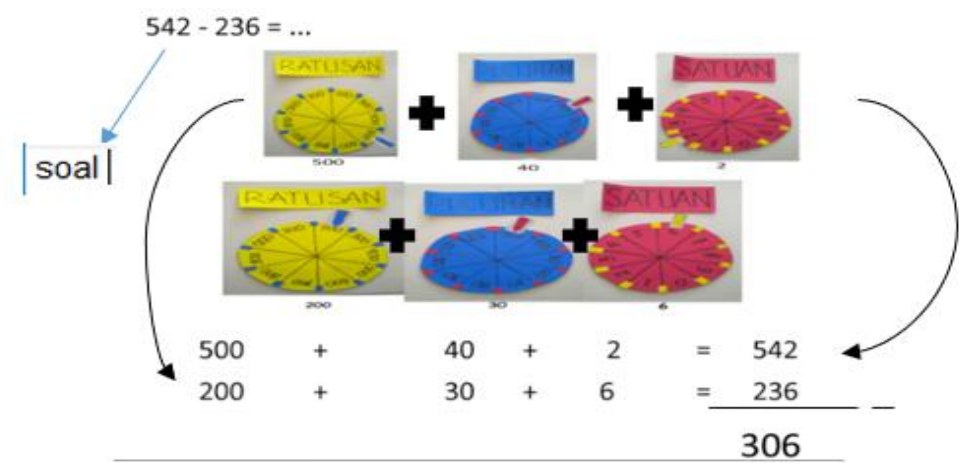

Gambar 3.9 Ilustrasi Pengurangan bilangan dengan Spedomatik

Data hasil aplikasi praktis inovasi pembelajaran yang dilaksanakan menggunakan Penelitian pengembangan pada media Spedomatik materi nilai tempat bilangan. Data didapatkan melalui aplikasi praktis media Spedomatik pada pembelajaran matematika materi nilai tempat bilangan di kelas 2 SD. Berdasarkan hasil aplikasi praktis, maka didapatkan data sebelum dan sesudah memanfaatkan media Spedomatik, yakni data uji coba 1 , dan data uji coba 2 . 
Hasil pembelajaran sebelum menggunakan media Spedomatik diperoleh rata-rata adalah 54,44, rata-rata pada uji coba 1 menggunakan media Spedomatik adalah 62,22, dan rata-rata pada uji coba 2 menggunakan media Spedomatik adalah 75,55. Berdasar hasil tersebut dapat dinyatakan terjadinya peningkatan pada hasil belajar siswa sebelum dan sesudah menggunakan media Spedomatik. Peningkatan tersebut dapat ditafsirkan sebagai peningkatan pemahaman konsep matematis siswa. Untuk itu dapat disimpulkan bahwa pembelajaran dengan memanfaatkan media Spedomatik mampu membuat pengalaman belajar siswa bertambah dan pembelajaran menjadi bermakna bagi siswa. Vonis akan hal tersebut dapat dilihat dari meningkatnya hasil belajar yang termasuk dalam ciri-ciri dari peningkatan pemahaman konsep matematis siswa.

Analisis praktis hasil pengaplikasian inovasi pembelajaran dilaksanakan dengan membandingkan dan melihat perbedaan hasil belajar siswa pada materi nilai tempat bilangan sebelum dan sesudah menggunakan media Spedomatik saat ujicoba 1 dan ujicoba 2. Berikut ini merupakan hasil belajar siswa sebelum memanfaatkan media Spedomatik pada materi nilai tempat bilangan.

Tabel 3.1 Hasil belajar sebelum menggunakan Spedomatik

\begin{tabular}{lccc} 
No & Banyak siswa & Nilai yang diperoleh & Jumlah \\
\hline 1. & 3 & 40 & 80 \\
\hline 2. & 1 & 50 & 50 \\
\hline 3. & 2 & 60 & 120 \\
\hline 4. & 1 & 70 & 70 \\
\hline 5. & 1 & 80 & 80 \\
\hline 6. & 1 & 90 & 90 \\
\hline & Rata-rata & $\mathbf{5 4 . 4 4}$
\end{tabular}

Kemudian berikut ini adalah hasil belajar siswa pada pembelajaran dengan menggunakan media Spedomatik yang dilaksanakan pada ujicoba 1.

Tabel 3.2 Hasil belajar setelah uji coba 1 Spedomatik

\begin{tabular}{lccc} 
No. & Banyak siswa & Nilai yang diperoleh & Jumlah \\
\hline 1. & 2 & 40 & 80 \\
\hline 2. & 2 & 50 & 100 \\
\hline
\end{tabular}




\begin{tabular}{|c|c|c|c|}
\hline 3. & 1 & 60 & 60 \\
\hline 4. & 1 & 70 & 70 \\
\hline 5. & 2 & 80 & 160 \\
\hline 6. & 1 & 90 & 90 \\
\hline
\end{tabular}

Dan setelah melakukan beberapa perbaikan pada media Spedomatik atas saran-saran yang masuk, berikut ini adalah hasil belajar siswa menggunakan media Spedomatik pada ujicoba 2.

Tabel 3.3. Hasil belajar setelah uji coba 2 Spedomatik

\begin{tabular}{|c|c|c|c|}
\hline No. & Banyak siswa & Nilai yang diperoleh & Jumlah \\
\hline 1. & 0 & 40 & 0 \\
\hline 2. & 1 & 50 & 50 \\
\hline 3. & 1 & 60 & 60 \\
\hline 4. & 2 & 70 & 140 \\
\hline 5. & 2 & 80 & 160 \\
\hline 6. & 3 & 90 & 270 \\
\hline
\end{tabular}

Hasil-hasil belajar diatas jika dimasukkan dalam perbandingan prosentase (\%), tampak terjadi peningkatan yang signifikan. Dari pra kondisi tanpa menggunakan media hingga ujicoba 1 dan ujicoba 2, aplikasi Spedomatik mengalami peningkatan secara bertahap. Peningkatan yang terjadi karena implementasi dengan memanfaatka media Spedomatik dalam menyelesaikan soal-soal nilai tempat bilangan. Secara utuh, grafik yang menunjukkan perbandingan prosentase hasil belajar siswa dapat dilihat pada diagram berikut ini: 


\section{Viagr ant Datany I ervanüingan ifasii Belajar dengan menggunakan media} Spedomatik

Pra Kondisi

Uji Coba 1

Uji Coba 2

Gambar 3.10 Grafik perbandingan hasil belajar

Atas dasar perbandingan hasil belajar yang telah dipaparkan diatas, kesimpulan yang dapat diambil dalam pembelajaran sebelum dan sesudah menggunakan media Spedomatik telah terjadi peningkatan hasil belajar. Dengan demikian penggunaan media Spedomatik dinyatakan mampu meningkatkan pemahaman konsep matematis, terlihat dari terjadinya peningkatan hasil belajar siswa. Peningkatan yang terjadi dikarenakan siswa aktif dan berperan langsung dalam memanipulasi media Spedomatik. Pernyataan tersebut senada dengan pendapat pendapat Muhsetyo (2007) yakni penggunaan media maipulatif mampu menyederhanakan konsep yang sulit kepada konsep yang konkret. Siswa yang malakukan aktivitas manipulatif tergolong dalam tahapan enaktif, yaitu siswa sedang menggunakan pengetahuan motoriknya untuk memahami.

Aktifitas dan kegiatan siswa ketika memanipulasi Spedomatik termasuk dalam proses pemahaman konsep matematis. Karena semua siswa dapat bebas berekplorasi setelah menggunakan Spedomatik, ada yang mencari nilai tempat bilangan, melakukan penjumlah bilangan dan melakukan pengurangan bilangan kemudian menjelaskan kepada temannya. Hal itu sesuai pernyataan dari Sanjaya (2009:76) tentang penguasaan konsep siswa, yang mana siswa dapat menjelaskan kembali konsep dalam cara dan bentuk berbedayang lebih mudah dipahami oleh dirinya sendiri. Cara memvisualisasikan hal abstrak tentang konsep nilai tempat bilangan yang dilakukan siswa memanfaatkan media Spedomatik sangat senada dengan 
pendapat Piaget (Slavin:2011) tentang tahapan operasonal konkret yang memiliki ciri dengan timbulnya pemikiran siswa yang logis.

Penyebarluasan atau diseminasi karya inovasi pembelajaran media Spedomatik dilakukan kepada rekan-rekan guru di SD Negeri Sumberwatu Sleman dan di KKG Gugus I Kecamatan Prambanan Sleman. Melalui diskusi dengan rekan sejawat, Spedomatik diharapkan dapat digandakan, minimal tiap kelas memiliki sendiri agar guru dan siswa di SD Negeri Sumberwatu Sleman dapat lebih bebas menggunakannya.

Ketika diseminasi dilakukan dalam lingkup KKG Gugus I Kecamatan Prambanan Sleman, peneliti mendapatkan banyak sekali saran, salah satunya adalah pada bahan yang dipakai disarankan dengan bahan yang kuat dan awet, seperti kayu atau triplek supaya tidak mudah rusak. Selain itu ada satu hal yang bagus untuk dijadikan rencana perbaikan media Spedomatik kedepannya, yaitu penyempurnaan pada penunjuk panah agar dapat diletakkan pada bagian tengah lingkaran agar lebih terlihat seperti spedometer aslinya.

\section{Penutup}

Penutup atau simpulan tidak sekadar mengulangi data, tetapi berupa substansi pemaknaan. Ia dapat berupa pernyataan tentang apa yang diharapkan, sebagaimana dinyatakan dalam bagian "Pendahuluan" yang akhirnya dapat menghasilkan bagian"Hasil dan Pembahasan" sehingga ada kompatibilitas. Selain itu, dapat juga ditambahkan prospek pengembangan hasil penelitian dan prospek aplikasi penelitian selanjutnya ke depan (berdasarkan hasil dan pembahasan).

Berdasar pada hasil kegiatan yang telah dilakukan tentang nilai tempat bilangan dengan memanfaatkan media Spedomatik, peneliti mengambil kesimpulan sebagai berikut: 1) Penggunaan dan penerapan media Spedomatik pada konsep pecahan di sekolah dasar secara valid mampu meningkatkan pemahaman konsep matematis dan hasil belajar siswa pada nilaitempat bilangan, 2) Media Spedomatik terbukti efektif diterapkan pada materi pokok nilai tempat bilangan di sekolah dasar. Terlihat dari keaktifan siswa saat memanipulasi media Spedomatik, 
disamping itu siswa terbantu dan merasakan pengalaman belajar yang menyenangkan dengan mengunakan media Spedomatik.

Atas dasar temuan dan simpulan yang telah dijabarkan sebelumnya, maka saran yang dapat disampaikan antara lain: 1) Media Spedomatik memiliki fungsi dasar peragaan pada tumbuhnya konsep berpikir siswa yang anstrak, sehingga perlu tahapan demi tahapan yang perlu dikembangkan agar siswa dapat bereksplorasi hingga mampu melepas konsep nilai tempat bilangan tanpa menggunakan media Spedomatik, 2) Media Spedomatik hnaya dapat digunakan pada kelompok kecil karena masih terbatas. Untuk itu diperlukan pengembangan lebih lanjut dengan menambah jumlah lingkaran dan lauas papan alas sehingga mampu menentuka nilai tempat bilangan lebih dari tiga digit angka pada bilangan. Selain itu kemasan Spedomatik juga dapat disempurnakan agar lebih mudah dan flesibel jika digunakan secara individual.

\section{Ucapan Terimakasih}

Ucapan terima kasih saya sampaikan kepada Direktorat Pembinaan Guru Pendidikan Dasar, Dirjen Guru dan Tenaga Kependidikan, Kementerian Pendidikan dan Kebudayaan, Dinas Pendidikan Kabupaten Sleman, Kepala Sekolah, dan rekan-rekan guru di SD Negeri Sumberwatu Sleman yang telah membantu dan memberikan kesempatan sehingga saya dapat menulis artikel ilmiah ini dan mengikuti lomba Inovasi Belajar (INOBEL) Guru SD tingkat Nasional.

\section{Daftar Referensi}

Arsyad, A. (2013). Media pembelajaran. Depok: PT. Rajagrafindo Persada.

Ashlock, R. B. 1994. Error Patterns in Computation. (6th ed). Englewood Cliffs, NJ: Prentice Hall.

Boggan, et. al. (2010). Using Manipulative to Teach Elementary Mathematic. Jornal of Instructions Pedagogies, pp 1-6 (online) http://www.aabri.com/manuscripst/10451.pdf diakses 23 Mei 2019

Garlikov. 2004. The Concep and Teaching of Place Value, (Online), (http:/ / www.garlikov.com/PlaceValue.html), diakses 23 Mei 2019) 
Marshall, L., Paul, S. (2008). Exploring the Use of Mathematics Manipulative Materials: Is It What We Think It Is?. Journal: IndoMS-JME Vol.5 No.2 Juli 2018, pp.148-159.

Mushetyo, dkk. (2007). Pembelajaran Matematika di SD. Jakarta: Universitas terbuka.

Sanjaya, W. (2009). Strategi Pembelajaran Berorientasi Standar Proses Pendidikan. Jakarta: Pranada.

Siswanto, R., Sugiono, S., \& Prasojo, L. (2018). The Development of Management Model Program of Vocational School Teacher Partnership with Business World and Industry Word (DUDI). Jurnal Ilmiah Peuradeun, 6(3), 365-384. doi:10.26811/peuradeun.v6i3.322.

Novita, R., \& Putra, M. (2017). peran desain learning trajectory nilai tempat bilangan berbantukan video animasi terhadap pemahaman konsep nilai tempat siswa kelas II SD. Jurnal Pendidikan Matematika, 11(1), 43-56.

Payne, J. N. \& Huinker, D. M. 1993. Early Number and Numeration; dalam Jensen, R.J. (Ed.), Reasearch Ideas for the Classroom: Early Childhood Mathematics. (hlm. 43-70). New York: National Council of Teachers of Mathematics Research Interpretation Project/Macmillan Publishing Company.

Relawati, I. (2012). Penggunaan Media Bendera Warna Untuk Meningkatkan Prestasi Belajar Matematika Pada Materi" Nilai Tempat" Siswa Kelas II SD Negeri Temas 02 Batu (Doctoral dissertation, University of Muhammadiyah Malang).

Seputra, T. MHT \& Amin, S. M. 1994. Matematika 1b: Mari Berhitung untuk Sekolah Dasar Kelas 1 Cawu 2. Jakarta: Depdikbud-Balai Pustaka.

Schweyer, S.R. (2010). The Effective Use of Manipulative (online) http://www.gphillymath.org/ExempPaper/Documents/manipulative. pdf diakses 23 Mei 2019.

Slavin, Robert. E. (2011). Psikologi Pendidikan Teori dan Praktik Edisi 9 jilid 1. Jakarta: Indeks.

Sudjana, Nana. (2009). Penilaian Hasil Proses Belajar Mengajar. Bandung: PT. Remaja Rosdakarya.

Sundayana, R. (2014). Media dan Alat Peraga dalam Pembelajaran Matematika. Bandung: Alabeta.

Thiagarajan, S., Semmel, S.D. \& Semmel, M. I. (1974). Instructional Developmentfor Training Teachers of Expectional Children: a Sourcebook. Bloomington: Indiana University. 